\title{
Goldsmiths' Work in the Dark Ages
}

\author{
A Short History of Its Progress, and the Various Schools of Art
}

\author{
By Sir William Martin Conway, M.A., F.S.A.
}

THE seventh and eighth centuries B. C. were for the Greeks something like the sixteenth and seventeenth
centuries A. D. for the peoples of Western Europe-a centuries A. D. for the peoples of Western Europe-a
great colonizing age. From Marseilles in the west to the great colonizing age. From Marseilles in the west to the Crimea in the east, Greek colonies or trading centers and factories sprang up at all sorts of suitable points on along the north shore of the Black Sea by Milesian colonists in the seventh century. "The Euxine coast," Mr. E. H. Minns tells us, "was the first El Dorado, the Mr. E. H. Minns tells us, "was the first El Dorado, the
first mysterious land, to draw adventurers across broad first mysterious land, to draw adventurers across broad
seas in search of fame and treasure." Thus arose Olbia, seas in search of fame and treasure." Thus arose Olbia,
Panticapæum (the modern Kerch), and many more once thriving settlements. What they throve on was trade. By sea they were in communication with the Greek cities; by land with the Scythians of the steppe, which stretches away without break far to the west, north, and east into the heart of Asia. Their wealth and taste are east into the heart of Asia. Their wealth and taste are
proclaimed by the vast quantities of treasures, made of proclaimed by the vast quantities of treasures, made of
gold and often set with precious stones, which the graves in this region have yielded. The gold may have come from north or south.. In any ease, the Scythians loved golden ornaments, and the Greeks provided such for two classes; the work respectively of Greek and of local artists. The former are sometimes purely Greek, alike in design and in technique, but oftener they bear evidence of the taste of the people for whom they were made. The latter are massive, ugly, and barbaric alike in design and in execution. These two schools existed side by side throughout the centuries. The barbarian school, with its clumsy representations of beasts and fabulous creatures, and its love of colored stones, was Asiatic in character. One of its most prominent characteristic was the inlaying of colored stones, oftenest garnets, in a random fashion into the substance of the gold. The Greeks, after the campaigns of Alexander, under the influence of the inroad of Orientalism that followed influence of the inroad of Orientalism that followed,
adopted the setting of precious stones in their jewelry as a fashion increasingly popular. The stone most commonly employed was the garnet.

In the first century of the Christian era the manufacture of golden ornaments still went forward in the cities founded by the Greeks on the north side of the Black Sea. We may call these works the product of the Bosporan School. Some treasures were dug up at Siverskaja, in the Kuban district in South Russia. The most striking of these are two Roman glass vessels, elaborately mounted in gold and garnets. One is of simple vase form. The mounts consist of two decorated horizontal bands of gold---one round the shoulder, the other haltway down toward the foot. These bands are connected by a few vertical strips of decorated gold. The strips are set with garnets in a dog-tooth pattern. From the upper band slender gold chains hang at frequent intervals, in all upward of a score in number. Gold balls are at the all upward of a score in number. Gold balls are at the
lower ends of the chains. The other vessel is a twolower ends of the chains. The other vessel is a two-
handled cup, with a broad gold band round the lip, on which cabochons are set, each beld by a ribbon of gold closely fitting around it. Between them are knobs of gold, covered with tiny gold balls. Chains, more numerous than on the other cup, hang from this rim, and each ends in a ball of garnet, with a gold ball hanging beneath it. These cups should be compared with certain chalices in the Treasury of St. Mark's at Venice, which were in the Treasury of St. Mark's at Venice, which were
looted by the Venetians in 1205 from St. Sophia and other looted by the Venetians in 1205 from St. Sophia and other
churches at Constantinople. Eleven of these chalices present one remarkable feature: from the lower part of the lip-rim of each there hang a series of fine wires, each originally furnished at the lower end with a pearl. These pendant pearls are the direct descendarts of the chains and balls of the Siverskaja cups, and the jeweled liprims of the chalices likewise preserve the ancient traditional mounting of the Bosporan School. The Siverskaja cups are not later in date than the first century A. D. The Venice chalices may be approximately dated to the Venice chalices may be approximately dated to the
eleventh century. Another feature which the South Russian and the St. Sophia vessels have in common is the vertical straps of metal by which the upper and lowe rings of the mounts are held together. This trick, if we may so call it, spread over Europe, and did not remain characteristic of Byzantine cups alone; but it is
excessively common in Byzantine cups, and was no excessively common in Byzantine eups, and was no
doubt copied from them by Western eraftsmen, who doubt copied from them by Western craftsmen, who
only occasionally employ it, and never until they had fallen under Byzantine influence.

of contemporary finds farther west in the heart of
Europe, only two call for brief mention. Both wer discovered in Hungary. The first is the Osztropataka
find : it consisted mainly of works of Imperial goldsmiths, the most important being an oval fibula formed of a great onyx, framed in a rim of characteristic openwork, such as was fashionable in parts of the Roman world at that time. The necklets, cups, and long fibulas were all of Roman workmanship. Some embossed silver plates formed part of another find close by, but the animals in relief on these had no barbarian connection. The bulk relief on these had no barbarian connection. The bulk
of these objects must be regarded as of Imperial and some of them of provincial Roman make.

The third and fourth centuries were a critical time in the history not merely of goldsmitby, but of European art, because it was at this time that the Goths (who in the latter part of the second century had left their settled abodes in the lands near the mouth of the Vistula and moved southward) were brought in contact with the civilization and art of the region north of the Black Sea. They there acquired a taste for jewelry of the Bosporan type, and this taste presently spread through the whole Teutonic world and became an important factor in the growth of the mediæval Gothic art that was to arise in the west. It appears to have been the invasion of the Huns about $376 \mathrm{~A}$. D. that set the peoples in movement and so helped to spread the new art style. It is thus of great interest to observe what the Bosporan style was in the fourth century, and how many of its traditions in the fourth century, and how many of its traditions
were directly absorbed by the artists of, or who worked were directly absorbed by the artists of, or who worked
for, the Gothic people. The most important group of jeweled treasures of the fourth century definitely Bosporan in type belong to the Berlin Museum, and were found in a grave or catacomb at Kerch., Along with a brooch was found a diadem as markedly barbarian as the brooch is Imperial. The famous Petrossa find contains eled cups, evidently Sassanian. In their present condieled cups, evidently Sassanian. In their present condi-
tion they resemble open-work baskets, but the open tion they resemble open-work baskets, but the open
spaces were once filled with plate-set stones. We arrive spaces were once filled with plate-set stones. We arrive
at exactly the method of mounting stones which is exemplified by the Jelalabad reliquary and the Ardeshir strapend. So far as we yet know, such work was only made in Persia at this date. The beast handles are likewise characteristically Persian. It is plain enough that these ornaments are not of the Bosporan school as we have thes far made acquaintance with it. Every indication leads to the conclusion that we have here examples of the best work of third or fourth century Sassanian gold-
berion best work
smiths.

After the third or fourth century there is little, if any, work discoverable done by Bosporan craftsmen for Scythian patrons. Thenceforward they worked for the Goths, who by war, pillage, and expansion were growing richer from decade to decade. Whether they worked as valued slaves or free craftsmen we cannot tell. As soon as the true folk-wandering epoch set in, golden and as the true folk-wandering epoch set in, golden and
jeweled ornaments were the only kind of artistic products for which wandering ehieftains had much use. Tho bulk of the fifth century barbarian ornaments is very poor stuff, but among it we find a few admirable works. One thing is practically certain, the Bosporan region did not remain an important center of art after the fourth century. The best workmen having gone to more mained relapsed, so that such works of the school, few mained relapsed, so that such works of the school, few
in number, as are discovered near Olbia or Kerch, dating from the fifth or sixth century or thereabout, are rude and poor in quality and design.

The sixth century in Western Europe was a period of decadence for barbarian jewelry. If the original impulse toward that art came from the Bosporan region, and the fine work of the fourth and fifth centuries was made by civilized craftsmen, unless those craftsmen could be reinforced by continued intercourse with the home be reinforced by continued intercourse with the home
of their art, or quickened by a genuine artistic impulse in the people for whom they worked, nothing but decadence could occur. Neither of these vitalizing influences arising, decadence took place. To this sweeping condemnation of barbarian jewelry north of the Alps an exception must be made in respect of three kinds of earrings and the hairpins associated with them; but so great is the contrast between them and other objects found with them that it seems necessary to conclude that they were imported from some more artistic center of manufacture. Plenty of instances could be cited of Coptic influence
in the west of Europe in the seventh century, but a digression on that subject here would carry us too far. The jeweled round brooches are of great variety, very
numerous, and many of them of a high order of decorative beauty. In type they descend from the roundel of the first century from Siverskaja, described at the beginning of this paper. Though of Bosporan origin, it was not in Continental Europe, nor at the hands of barbarians, that the type was preserved and developed. That was done somewhere else, and suddenly in the sixth was done somewhere else, and suddenly in the sixth west, and rapidly became popular. In the seventh century local artificers may have imitated it, and many of the surviving specimens may be their handiwork. But barbarian jewelers of the seventh century stood on a very different level from their rude predecessors, and to them we must turn our attention. Now for the first time in barbarian lands we meet with a named artist, and he is not a painter, sculptor or architect, but a goldsmith, nor is he a man of the artisan class, but a bishop and Minister of State-St. Eloy (born $c .588 ; o b . c .665$ ). His perici of activity was about from 610 to $66.5 \mathrm{~A}$. D. He started life as apprentice to a goldsmith at Limoges, so that we thus have evidence of a settled manufacture at least as early as the very beginning of the seventh century, and this where we should look for it - in the southern part of France, which had been least damaged by the barbarian infiitration.

At this time in Western Europe, as far north as Eng land, a considerable revival of art took place; but it was not primarily a revival of the older leading arts (architecture, sculpture, and so forth), but of the art of the goldsmith. Art patrons doubtless caused to be erected churches and other new buildings; but what they loved above all else was work in the precious metals and jewels, and these then began to be made for them in great abundance. It is enough to read superficially in the history of the Merovingians to recognize that no works of art could give so much pleasure to the princes of that time as those which could be easily carried about. Hence an intense demand for goldsmithy, which from the seventh century onward till the tenth became and maintained itself as the leading art in all the barbarian lands. We may therefore conclude that from about the latter part of the sixth century goldsmiths became settled, active, and presently important craftsmen, rising in a few
decades to the position of the leading artists of their day in the kingdoms of the west.

The last great seventh-century goldsmith was the craftsman who seems to have worked in Kent for the Royal Court there, perhaps at Faversham. This man or school is best represented by the wonderful Kingston brooch-as fine a jewel as any produced in Europe in its day. It was found on Kingston Down, Kent, and is now a principal-perhaps the principal-treasure of the Liverpool Museum. Certain it is that the art of this craftsman did not arise in Kent; but in Kent it receiver a new application and was wedded to a markedly loeal style of design. It is impossible to mistake the works of this atelier for those of any other. To it we may unquestionably assign a whole group of round brooches and inlaid buckles, all of finest quality. It is safe to assume that the head of this school of goldsmiths was no obscure artisan, but a man probably like St. Eloy, of high and influential position.

We thus reach the end of this rapid purview of the history of the rise of the goldsmith's craft among the barbarian peoples who poured into the Roman world and overwhelmed and destroyed so much that was precious. It has of late been customary to assign to them artistic gifts of their own of too high an order. That they brought a new spirit and much new blood into the west is obvious enough; that this new spirit ultimately gave birth to new and glorious kinds of art is likewise clear. But it is not true that they carried from the borders of the Black Sea the germs of an art which they themselves developed into something great. It was not until most of their moving and fighting and pillaging was done, and they had settled down in their new homes, that they turned to the lands of ancient eivilization anid found among the wrecks of its population enough survivors who still cherished the craft traditions of their ancestors to be able by them to create for the new men of power and wealth works of art incorporating indeed the new ideals, but expressing them by aid of a longof a papr rea before the Royal Archeological Institute. 